\title{
Analysis and Evaluation of Fiscal Policy in Latvia
}

\author{
Ẽrika Žubule \\ Faculty of Economics and Management \\ Rezekne Academy of Technologies \\ Rezekne, Latvia \\ erika.zubule@rta.lv
}

\begin{abstract}
The choice and topicality of the research topic is based on the fact that upon strengthening of the government's regulating role in economy, the notion of public finances positions itself, and state budget has become an important subject of both economic and political discussions as implementation of fiscal policy is takes place through it. In order to evaluate fiscal policy, it is necessary to evaluate the potential influence of different fiscal policy instruments on social and economic situation in the state. Aim of the research - to evaluate activities of fiscal policy implemented in Latvia in context of certain tax, namely, influence of corporate income tax on state's economic and financial indicators, identifying the main risks and imperfections of fiscal policy when ensuring state's budget. Applying simulation methods in the environment of Matlab/ Simulink, the authors analyze and evaluate the influence of fiscal decisions and their implementation on the situation in Latvia, analyzing the most important tendencies in the sphere of corporate income tax payments according to the tax reform commenced in 2018.
\end{abstract}

Keywords-budget revenue, corporate income tax, fiscal policy, fiscal risk, gross domestic product.

\section{INTRODUCTION}

The choice and topicality of the research topic is based on the fact that upon strengthening of the government's regulating role in economy, and thereby positioning the notion of public finances, state budget has become an important subject of both economic and political discussions. Consequently, the influence of government's fiscal implemented measures on the development within the state becomes topical, implementing the policy of taxes and government expenditure.

Therefore there is a view that in order to enable evaluation of fiscal policy, it is necessary to pay attention not only to the aims defined by the government activity, but also to evaluate the potential influence of different fiscal policy instruments on social and economic situation in the state.

Aim of the research - to evaluate activities of fiscal policy implemented in Latvia in context of certain tax, namely, influence of corporate income tax on state's economic and financial indicators, identifying the main

\author{
Peter Grabusts \\ Faculty of Engineering \\ Rezekne Academy of Technologies \\ Rezekne, Latvia \\ peteris.grabusts@rta.lv
}

risks and imperfections of fiscal policy when ensuring state's budget, and to suggest recommendations for improving the capacity of fiscal measures.

Applying simulation methods Matlab/Simulink environment, the authors in the research, on the basis of the study carried out before [1], evaluate the influence of fiscal decisions and their implementation on the situation in Latvia, analyzing the most important tendencies in the sphere of corporate income tax payments according to the tax reform commenced in 2018 .

Methods used in the research - monographic, logical and constructive, content analysis, comparative method for views and conceptions as well as situation simulation method.

\section{LiterATURE REVIEW}

In the literature on economics and in the financial practice in the countries the conception "state fiscal risk" has only recently been topical in connection with the beginning of the economic crisis in the USA in 2007 and later on also in the European countries. The crisis reached Latvia, too, which negatively influenced the process of the formation of the state budget increasing the state budget deficit and the government debt. As we know, in the period of 2009 until 2011 there was a very painful consolidation process of budget in Latvia. For the development of financial and economic theory and practice the role of fiscal policy measures (taxes, government's expenses, loan) is emphasized for potential opportunities of governments to regulate social and economic activities in country.

Fiscal policy plays an important role in public economy. It is a tool for government to impact the market of goods and services, financial and labour market as well as solve the problems of redistribution of income and social justice [4].

It is emphasized that when evaluating application of instruments of fiscal policy it is important to understand the cycle of economic development - economic growth, high level of demand, supply and general wellbeing of population interchanges with periods, when growth rates decline and so do the income of the employed, having 
a negative impact on common demand for goods and services. Thus a government can purposefully intervene in economic processes using instruments of fiscal policy in order to renew economic stability and ensure sustainable development in a long term [5], [6].

Fiscal policy is implemented through national budget, namely, receipts, expenditures planning and ensuring for performance of governmental functions. Despite the persisting view that budgeting is related to mathematical methods and ability to work with numbers, nevertheless it is emphasized that all the decisions on development of national financial plan should be perceived not only in the economic, but also political context [7].

It is possible to assert, that it is updated also in the legislation of the Republic of Latvia: budget - a mean for implementation of national policy through financial methods. Consequently, national budget is the most important instrument in implementation of fiscal policy; basically it is a financial plan of income and expenditure for a certain period of time developed by the executive power and approved in the procedure of legislation [8].

Success and failures of each country's economic development depend on how successful was the conception chosen by the government activity, namely, whether it corresponds to the specific time and economic conditions (social, economic, political, geopolitical factor).

It is possible to state, that fiscal policy measures implemented in good time and corresponding to economic situation is a crucial precondition in order to achieve a sustainable development of national economy.

\section{MATERIALS AND METHODS}

The methodology of the research is related to the aim set and tasks to be accomplished, that is, to analyse the research published in scientific literature on fiscal policy, its feasibility. It means, that important how can to find correlation with economic development, income in the budget and concrete tax payments. The authors have used the goal to catch up with Matlab/Simulink tool for economics process modelling.

Simulation - the most powerful and versatile method for studying and evaluating the effectiveness of systems, the behavior of which depends on the influence of random factors [8].

The implementation of such opportunities in the universal programming language is a difficult task. Currently, there is quite a lot of software that allows to model processes. However, now there is a product that allows solving these problems quite effectively - the MATLAB package [9], [10], [11] containing a visual simulation tool - Simulink. Simulink - a tool that allows you to simulate the system quickly, get the indexes of expected effect and compare them with the amount of effort required to achieve them [12], [13].

Of particular interest for simulation is a Simulink tool designed specifically for modelling dynamical systems. It has a library of standard graphics units with built-in mathematical functions. It is sometimes called a tool of visual modelling [14], [15].

Although Simulink is designed mainly to solve engineering and scientific- technical problems, the possibilities of its use are almost unlimited. The input of initial parameters is made interactively by graphics assembly of elementary blocks circuit diagram, resulting in a model of the studied system. The blocks included in the model relate to each other both in information and in management. The type of connection depends on the type of the block and the logic of the model.

The Simulink program is an application to the MATLAB package. Using Simulink program the simulation implements the principle of visual programming whereby the user on the screen creates a model of a structure, process or system from standard blocks of the library, and performs calculations. In this case, unlike in classical ways of modelling, the user does not need to study the programming language and numerical mathematics methods thoroughly, there is enough to have some general knowledge required when working on the computer, and, of course, knowledge on the subject area in which one works.

Creating a model in this way, and then launching it, it is possible to see the results of modeling. In the simulation, the user can choose the method for solving equations, as well as the way to change the model time (with a fixed or variable step). During the simulation, it is possible to monitor the processes happening in the system. To this purpose, special viewing devices that are part of the Simulink library are used. The simulation results can be presented in the form of graphs or tables.

\section{RESEARCH RESULTS}

The tax reform commenced in Latvia in 2018 was basically grounded in issues discussed in the society: reduction of employment taxes, adoption of Estonian practice in relation to corporate income tax, changes of capital income imposition procedure etc. While evaluating the solutions offered by the government, the authors stated that nevertheless there might arise issues on efficiency of fiscal measures and their influence not only on budget income, but also on social and economic aspects.

The authors chose corporate income tax as the most important research object in the sphere of tax changes, performing evaluation of its influence on GDP and national budget before and after implementation of tax reform. The authors carried out analysis of statistical data, comparing the current situation and prognosticating a potential development scenario of public finances for the following years (see Table I).

The expected and factual GDP indicators are illustrated in Figure 1.

It can be concluded that the expected GDP development trends show an increase. However, calculations of the authors indicate that there is much more rapid GDP growth to be planned. It means that when making decisions in the 
context of fiscal policy establishment one must not ignore the potential scenarios of macroeconomic development, taking into account various influencing factors.

It must be emphasized that it is planned to submit the national draft budget 2019 to Saeima in the beginning of March, and it could come into effect after the middle of April. Consequently, there was made a decision, that it is not expedient to develop medium-term budget framework for this year, as macroeconomic prognoses of the previous year would be used for calculations in this case. Moreover, in this autumn a medium-term budget framework will have to be developed already for the next three-year period [16].

TABLE I. GDP, CIT AND THE GOVERNMENT BASIC BUDGET REVENUES IN LATVIA IN THE YEARS 2014-2022

\begin{tabular}{|l|c|c|c|c|c|c|c|c|c|}
\hline Year & $\mathbf{2 0 1 4}$ & $\mathbf{2 0 1 5}$ & $\mathbf{2 0 1 6}$ & $\begin{array}{c}\mathbf{2 0 1 7} \\
\text { (progno- } \\
\text { sis) }\end{array}$ & $\begin{array}{c}\mathbf{2 0 1 8} \\
\text { (progno- } \\
\text { sis) }\end{array}$ & $\begin{array}{c}\mathbf{2 0 1 9} \\
\text { (prognosis) }\end{array}$ & $\begin{array}{c}\mathbf{2 0 2 0} \\
\text { (prognosis) }\end{array}$ & $\begin{array}{c}\mathbf{2 0 2 1} \\
\text { (progno- } \\
\text { sis) }\end{array}$ & $\begin{array}{c}\mathbf{2 0 2 2} \\
\text { (prognosis) }\end{array}$ \\
\hline GDP & 23600 & 24378 & 25072 & 26403 & 27905 & 29615 & 30360 & & \\
\hline GDP Factually & & & & 27033 & 29424 & 31293 & 33663 & 34950 & 36861 \\
\hline Budget & 4939 & 5093 & 5281 & 5760 & 6336 & 6256 & 6090 & & \\
\hline Budget Factually & & & & 5387 & 6324 & & & & \\
\hline CIT & 354 & 383 & 407 & 425 & 461 & 468 & 498 & & \\
\hline CIT Factually & & & 419 & 425 & 304 & & & & \\
\hline
\end{tabular}

(Data from dark cells- according to predictable data of the Ministry Economy of Latvia -On the medium-term budgetary framework for 2017, 2018 and 2019 years).

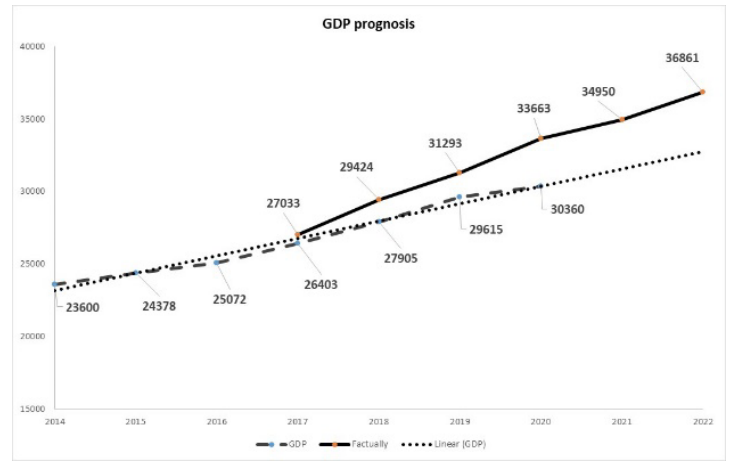

Fig. 1. Factual and expected GDP values in Latvia during 20142022 (X-axis: year; Y-axis: GDP values).

It must be emphasized that it is planned to submit the national draft budget 2019 to Saeima in the beginning of March, and it could come into effect after the middle of April.

As GDP indicator ensures the component of revenue for the national budget, also the numeric values of potential revenue for budget correlates according to prognoses of GDP indicators (see Fig. 2).

Trend line (dotted) shows that revenue for the budget should increase until 2023. Nevertheless, the authors believe that the situation in ensuring Latvian fiscal policy depends on several factors: political decisions in the country, geopolitical aspects, economic and social situation in general.

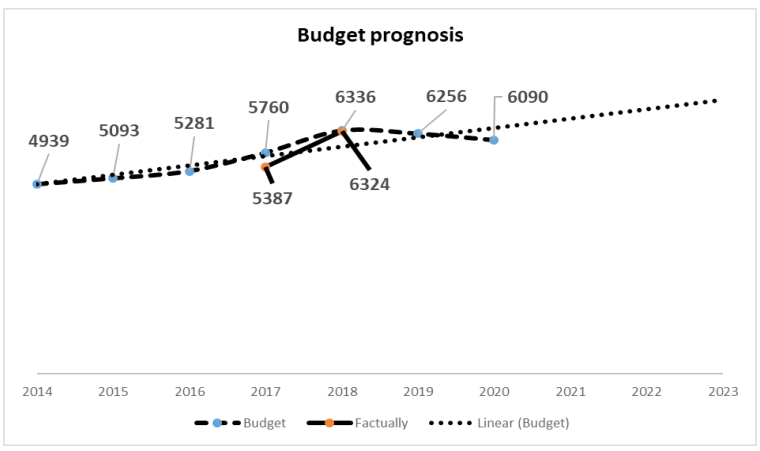

Fig. 2. Factual and expected values of Latvian national basic budget (X-axis: year; Y-axis: Budget values).

The authors accentuate corporate income tax as the most significant research object in the sphere of taxes. Consequently there is performed evaluation of its influence: development trends, influence on national economic indicators, mostly GDP (see Fig. 3).

It should be emphasized that CIT prognosis also shows an upward trend; however, currently the actual values do not correspond to the expected ones.

It is possible to conclude that in the framework of tax reform the major changes happened in the sphere of corporate income tax, stipulating the tax to be paid upon division of profit instead of imposing it on the derived profit as it was before. It also influenced the indicators of revenues for the national budget for 2018. In 2018, corporate income tax revenue was 304.00 million euro. Comparing with 2017, it decreased by 121.61 million euro or $28.6 \%$. However, the forecast of revenue for corporate income tax has been reached at $130.6 \%$, in other words, revenue is 71.30 million greater than it was planned [17]. 


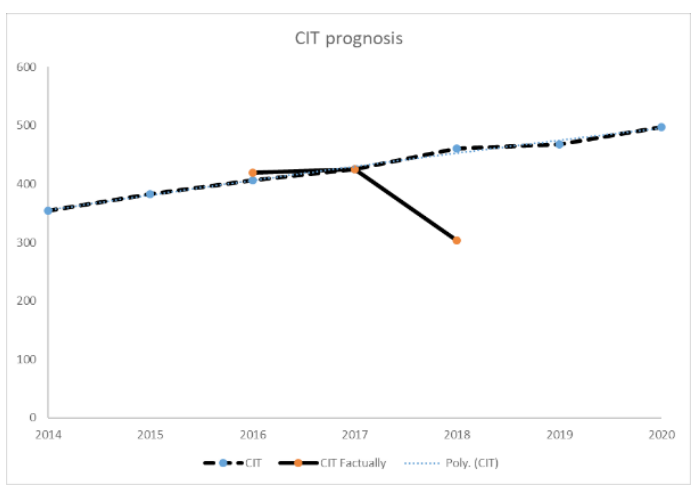

Fig.3. The expected and factual values of Corporate income tax (X-axis: year; Y-axis: CIT values).

In order to make up the simulation of CIT influence on the economy and the fiscal situation in the country, a simple Matlab/Simulink model was derived which calculated the proportion CIT/GDP (see Table II and Fig. 4).

TABLE II. The EVALUATION CRITERIA OF THE CIT Influence ON THE GDP

\begin{tabular}{|l|l|l|l|l|l|l|l|}
\hline Year & $\mathbf{2 0 1 4}$ & $\mathbf{2 0 1 5}$ & $\mathbf{2 0 1 6}$ & $\mathbf{2 0 1 7}$ & $\mathbf{2 0 1 8}$ & $\mathbf{2 0 1 9}$ & $\mathbf{2 0 2 0}$ \\
\hline $\begin{array}{l}\text { CIT/ } \\
\text { GDP }\end{array}$ & 1,50 & 1,57 & 1,67 & 1,58 & 1,03 & 1,50 & 1,48 \\
\hline
\end{tabular}

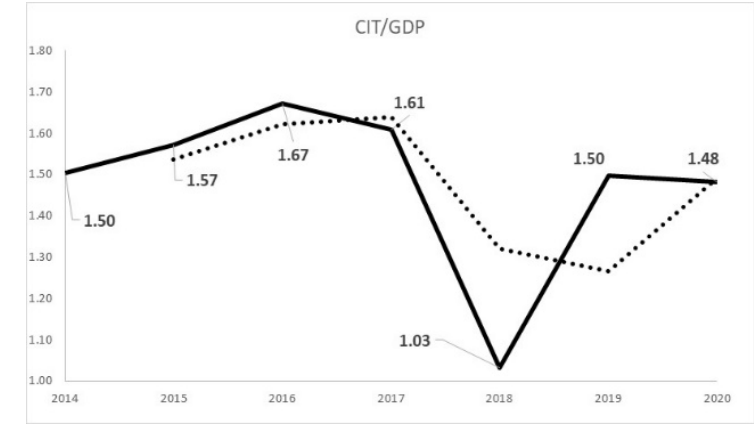

Fig. 4. The influence of CIT on GDP according to the existing legislation of the Republic of Latvia (X-axis: year; Y-axis: CIT influence on the GDP values).

The dotted trend line shows that according to the forecast there should not have been such a rapid decline of the proportion of CIT/GDP in 2018; however, as emphasized before, it is related to the aspects of tax reform implementation in the context of CIT application.

Despite the fact that further forecasts show a positive trend, the authors' opinion is that Latvian authorities (Ministry of Finance, Ministry of Economics) when implementing fiscal policy have to ensure high quality capacity in the implementation of the initiated reform (analytical evaluation, understanding the real situation, ensuring proper tax administration).

With the aim to make up the simulation of the CIT influence on the economy and fiscal situation in the country a simple Matlab/Simulink model was elaborated which calculated the proportion CIT/GDP (see Fig. 5).

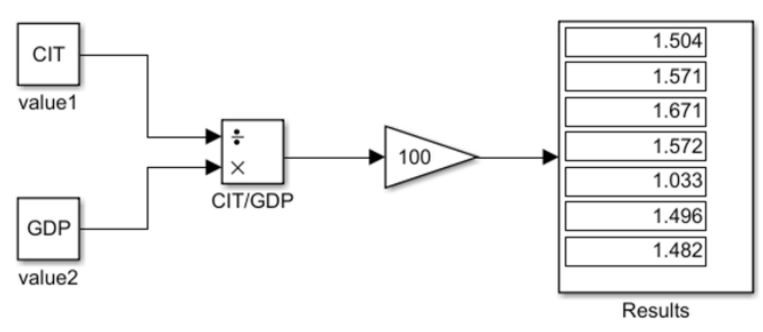

Fig. 5. The evaluation model of the influence of the CIT.

\section{CONCLUSION AND PROPOSALS}

Fiscal policy plays an important role in public economy. It is a tool for government to impact the market of goods and services, financial and labour market as well as solve the problems of redistribution of income and social justice.

Government can purposefully intervene in economic processes using instruments of fiscal policy (tax, expenditures, loan), in order to renew economic stability and ensure sustainable development in a long term. It is possible to state, that fiscal policy measures implemented in good time and corresponding to economic situation is a crucial precondition in order to achieve a sustainable development of national economy.

National budget is the most important instrument in implementation of fiscal policy; basically it is a financial plan of income and expenditure for a certain period of time developed by the executive power and approved in the procedure of legislation.

Simulation - the most powerful and versatile method for studying and evaluating the effectiveness of systems, the behavior of which depends on the influence of random factors. It can be concluded that Matlab/Simulink tool is a very suitable tool not only in economics calculations, but also can serve as a simulation model visualization tool in various science fields.

In Latvia according to the forecast there should not have been such a rapid decline of the proportion of CIT/ GDP in 2018; it is related to the aspects of tax reform implementation in the context of CIT application.

When making decisions in the context of fiscal policy establishment one must not ignore the potential scenarios of macroeconomic development, taking into account various influencing factors (political decisions in the country, geopolitical aspects, economic and social situation in general).

Despite the fact that further forecasts show a positive trend, the authors' opinion is that Latvian authorities (Ministry of Finance, Ministry of Economics, SRS) when implementing fiscal policy have to ensure high quality capacity in the implementation of the initiated reform. 


\section{REFERENCES}

[1] E.Žubule, P.Grabusts, L.Kavale, "Creation of Innovative Approach for Study of the National Fiscal Space, ” Proceedings of the 11th International Conference "Environment.Technology. Resources", Rezekne,June,15-17, 2017, Vol.2., P.189-195. http:// dx.doi.org/10.17770/etr2017vol2.2574

[2] J.M. Keynes, The General Theory of Employment, Interest, and Money. Routledge, Taylor \& Francis Group, 2017.

[3] Macroprudential Policy and Practice. In P. Mizen, M. Rubio, \& P. Turner (Eds.), Macroprudential Policy and Practice (Macroeconomic Policy Making, p. I). Cambridge: Cambridge University Press, 2018 https://doi.org/10.1017/9781108304429

[4] J.L. Mikesell, Fiscal Administration: Analysis and Applications for the Public Sector, Belmont, US, 2007.

[5] R. Allen, R. Hemming, and B.H. Potter, The International Handbook of Public Financial Management. Palgrave Macmillan, 2013.

[6] A. Alesina and S. Ardagna, "Large Changes in Fiscal Policy: Taxes Versus Spending. Taxpolicy and the Economy, " 24(1), 35-68, 2010

[7] Public Budgeting: Policy, Process and Politics, ed.by Rubin.I.S., ASPA, 2008.

[8] C. Kay, Mathematics for Computer Programmers. New Jersey: Prentice Hall, 1984.

[9] J. Kiusalaas, Numerical Methods in Engineering with MATLAB, 3e. Cambridge University Press, 2016, 430 p.
[10] T. Siauw and A. Bayern, An Introduction to MATLAB Programming and Numerical Methods for Engineers. Academic Press, $2014,340 \mathrm{p}$

[11] D. Smith, Engineering Computation with MATLAB, 3e. Pearson Education Inc, 2013, $464 \mathrm{p}$.

[12] D. Xue and Y. Chen, System Simulation Techniques with MATLAB and Simulink. John Wiley \& Sons, Inc, 2013, 488 p.

[13] P. Karel and Z. Tomas, "Multimedia Teaching Aid for Students of Basics of Control Theory in Matlab and Simulink," Procedia Engineering, Volume 100, 150-158, 2015.

[14] A.B. Shiflet and G.W. Shiflet, Introduction to Computational Science: Modeling and Simulation for the Sciences, 2e. Princeton University Press, 2014, 856 p.

[15] C.W. Silva, Modeling and Control of Engineering Systems. CRC Press, Inc, 2009, 766 p.

[16] "A medium-term draft state budget for 2019 will not be prepared," Feb. 7, 2019. [Online]. Available: http://www.saeima.lv/lv/aktualitates/saeimas-zinas/27647-videja-termina-valsts-budzeta-projektu-2019-gadam-negatavos [Accessed: March 10, 2019]. (in Latvian)

[17] "Summary of the implementation of the budget revenue share for the 12 months of 2018," Jan. 22, 2019. [Online]. Available: https://www.vid.gov.lv/lv/kopsavilkums-par-budzeta-ienemumu-dalas-izpildi-2018gada-12-menesos [Accessed: March 10, 2019]. (in Latvian) 